\title{
NEW ASPECTS OF NUTRITION
}

\author{
BY
}

\author{
J. R. MARRACK
}

From the Hale Clinical Laboratory. of the London Hospital

The siege of Madrid, which lasted from the end of 1936 to March 1939, gave the first opportunity for the use of the newer knowledge of nutrition in a study of the effects of a fairly uniform inadequate diet on a large population. After the first few months of this period the calories per head per day remained close to 1000 and the total protein about $66 \mathrm{gm}$.; but the amount of animal protein fell from 15.0 to $4.8 \mathrm{gm}$. The remarkable feature was that there were never more than about one hundred cases of any of the gross deficiency diseases among a population of about 100,000 (Jiminez Garcia, 1940). Even the manifestations of deficiency of some member of the B group of vitamins were different in different persons. One would get pellagra, with two of the classical three D's, dermatitis, diarrhoea and dementia; another pellagra sine pellagra-digestive disturbances and mental changes, without dermatitis; another would get glossitis; another optic neuritis; and another a paraesthesia. The incidence of paraesthesia and glossitis was twice as high among women as among men, while optic neuritis was twice as common among men as among women. Although the peak of incidence of pellagra, neuritis and optic neuritis occurred in the winter 1937-8, many cases escaped then to become victims in the following winter. It appears that even on a grossly inadequate diet the frank deficiency diseases attack only those who are specially susceptible and may only appear after a long period of deficient diet.

The restrictions of our food supply, at present, have not seriously reduced the amounts of any of the nutrients in our diet, except vitamin C. Scurvy and rickets may persist; but, with this experience of Madrid before us, we must anticipate that other frank deficiency diseases will be confined to people who are abnormal in constitution or food habits. What we must look for are, at most, minor manifestations; and these also, we may expect, will not be distributed uniformly throughout the population, but limited to the more susceptible and will appear only after a long period on a defective diet.

\section{Protein}

As far as metabolism is concerned we must regard food proteins as mixtures of the amino-acids into which they are split in digestion. A mixture of amino-acids injected intravenously will keep a human being in nitrogen equilibrium; the amount of amino-acid needed to maintain equilibrium is approximately the same whether the amino-acids are injected as such or derived from protein digested in the alimentary tract (Martin and Thompson, 1943).

Rats will not grow unless supplied with the following ten ' indispensable' amino-acids:

$\begin{array}{ll}\text { arginine } & \text { methionine } \\ \text { histidine } & \text { phenyl alanine } \\ \text { iso-leucine } & \text { threonine } \\ \text { leucine } & \text { tryptophane } \\ \text { lysine } & \text { valine }\end{array}$

Adult rats can, however, maintain weight and health when not supplied with lysine and may be able to make histidine, although not sufficiently fast to maintain normal growth.

So far, studies on human requirements of individual amino-acids have been limited to the maintenance of nitrogen equilibrium of adults over short periods. The nitrogen balance becomes negative if the mixture of amino-acids supplied does not include lysine, tryptophane, tyrosine, methionine, leucine, iso-leucine, valine and threonine (Holt et al., 1941). Arginine and phenyl alanine have not been tested. Nitrogen balance is maintained when histidine is omitted from the mixture, but it is possible that histidine may be made slowly and be 'indispensable' for normal growth and for repair.

Proteins of living cells and of milk and eggs contain more of the indispensable amino-acids, particularly arginine, lysine and histidine, than do the store proteins of cereal seeds. As the greater part of the protein, other than cereal, in our diet is derived from animal sources, the biological value of animal (first class) proteins is higher than that of vegetable (second class) proteins. However, the metabolism of any particular amino-acids taken in the food appears to be affected by the presence of others (Burroughs et al., 1939). This must be taken into account in the assessment of the biological value of diets. The value of a mixture of first- and second-class protein, eaten together, may be higher than the sum of the values of the two taken separately. Thus over half of the protein in four R.A.F. messes was derived from cereals; but Macrea and colleagues (1943) found that the value of this mixed protein was as high as those of liver and kidney proteins. 
It is comparatively easy to estimate the minimum amount of mixed protein that is needed to maintain nitrogen equilibrium. However, the optimum intake may be well above the minimum that is needed to maintain equilibrium, with a safety margin added. It is now possible to follow the metabolism of amino-acids given as food. Amino-acids can be synthesized with radio nitrogen in the amino group and heavy hydrogen in the aliphatic chain. These marked elemients can be detected in the tissues and excreta. This method has revealed a continual process of exchange, in which amino-acids absorbed from the intestine are incorporated, whole, into the proteins of the tissues or amino groups exchanged between tissue proteins and absorbed amino-acids (Schoenheimer, 1940). This continual process of flux disproves the older view that, in fully grown animals, limited quantities of amino-acids are used for purposes of repair or the formation of special products (such as creatine or insulin) while any surplus is promptly deaminized and metabolized as carbohydrate or fatty acid. It seems probable that the process may be influenced by both the amount and the nature of the amino-acids absorbed, and, therefore, by the quantity and quality of the protein in the diet. In fact a continual process of tissue rejuvenation depends on the character of the food. It would not be surprising if health were related to the rate of this rejuvenation. But there is no satisfactory evidence that any benefit is derived from increasing the protein intake above the U.S.A. standard (Table 1) and two adults, Röse (1934) and Rhyn (1941), claim to have lived for long periods on much smaller amounts.

Normal dogs have a reserve store of protein on which they can draw to replace losses of plasma protein or haemoglobin. This store is lost when the dogs are kept on a diet that contains too little protein to maintain nitrogen equilibrium. It seems probable that human beings have such stores, though smaller in proportion to their body weight. Dogs, with low plasma proteins and reserve stores exhausted, are liable to infections, and conversely infection interferes with the restoration of plasma protein or haemoglobin from food protein (Knutti et al., 1935; Whipple, 1942).

Protein-depleted dogs are extremely susceptible to damage to the liver by chloroform and other poisons. They can be protected against these poisons by the sulphur containing amino-acid, methionine, in amounts comparable with those in a large meal of meat. Choline, which has an effect similar to that of methionine in preventing accumulation of fat in the livers of rats fed on a high fat diet, does not protect, and the other sulphur containing amino-acid, cystine, is less effective than methionine (Whipple, 1942).

Famine oedema is a condition comparable to experimental protein depletion in animals. It appears among the general population only after it has lived for many months on a diet that supplies insufficient calories and is usually preceded by some infectious disease. The oedema is due to reduction of the plasma protein below 5 to $5 \cdot 5$ per cent. In Madrid cases numbered 2 or 3 per month until the end of 1938; then in January 1939, the number shot up to over 100 . When a survey was made in a suburb of Madrid in 1941 (Robinson et al., 1942) the average plasma protein was $6.9 \mathrm{gm}$. per $100 \mathrm{ml}$., that is, up to the level found among healthy well-fed people in Denver (Trevorrow et al., 1942). Even at this time, the total protein per man value was only $66 \mathrm{gm}$. per day and the animal protein $22 \mathrm{gm}$. It appears that human beings can not only maintain but even replenish their body protein on these low intakes.

Comparing our present allowances of foodstuffs with the average consumption as found in the Ministry of Labour survey of 1937-8, we find that the average consumption per head per week has fallen as follows: butchers meat $6 \mathrm{oz}$., fish about $4 \mathrm{oz}$., eggs 3. Milk consumption, during the months in which the supply is restricted, has risen slightly and considerably during the other months. The total effect is a drop in the average animal protein per head of about $6 \mathrm{gm}$. to about $33 \mathrm{gm}$. per day, with a total protein of about $70 \mathrm{gm}$. This estimate makes no allowance for supplementary meals in private restaurants, British restaurants and canteens, which may well raise the intake of animal protein of some 15 per cent. of the population by over $6 \mathrm{gm}$.

Owing to unequal distribution of meat and cheese within the family, housewives and children, who do not get meals away from home, may often get considerably less than the amounts recommended in the U.S.A.

When Röse (1934) lived for years on a minimum allowance of protein, he found that minor infections, such as colds (to which he seemed peculiarly liable) caused a negative nitrogen balance. In estimates of protein requirements we must allow a safety margin to cover such losses. Apart from these everyday incidents, more serious infections and injuries may cause great breakdown of body protein. After a simple fracture of tibia and fibula the loss of nitrogen may be as much as $137 \mathrm{gm}$., equivalent to the protein in nine pounds of muscle (Cuthbertson, 1935-6). Munro and Cuthbertson (1943) state that the protein lost after experimental injuries to animals may come from protein reserves. It is, however, hardly likely that human beings carry $137 \mathrm{gm}$. of nitrogen as reserve protein, since this is equivalent to about three times the protein in the liver; a considerable fraction of the loss must have come from muscle. After severe burns the depletion of protein may be much greater, as loss of protein, as such, from the site of injury, is added to loss by breakdown (Taylor et al., 1943). The plasma proteins may fall below the oedema level and healing be delayed. Patients may be unable to eat enough protein to restore the losses and recover only when they are given extra protein by stomach tube and amino-acids by injection.

Even after less severe losses, the rate of replacement of the lost protein will depend, in part, on the 
amount and quality of the food. It would take the protein of 30 days of the present food of a normal consumer to replace the lysine of the protein of $9 \mathrm{lb}$. of body tissue. The rate of rehabilitation will depend on the diet both before injury, since this influences the protein stores, and during convalescence.

\section{Fat}

Scarcity of fat was regarded as one of the greatest hardships of the food shortage in Germany and Austria during the last war. I have been told by people who have recently escaped from Holland that their chief complaint was the lack of fat, although the nominal total fat ration in Holland was $5 \mathrm{oz}$. per week, while the level of the bread and flour ration made it practically impossible to get enough calories. Rats need certain unsaturated fatty acids; but as far as the evidence goes, human beings can do without fats, apart from the few grams needed to assist the absorption of the fatsoluble vitamins. A man has lived for six months on a diet that supplied not more than $5 \mathrm{gm}$. per day of fat; rats fed on this diet showed typical symptoms of fatty acid deficiency (Brown et al., 1938). Certain fats, butter for example, are important foodstuffs, because they contain fat-soluble vitamins. But the chief value of fats, at the present, is that they are compact forms of fuel and make other foodstuffs more palatable. A slice of bread and butter may supply twice as many calories as the bread alone and appear less filling.

\section{Carbohydrates}

Even sugar may have some special function that has, so far, not been recognized. In spite of the evidence, there has always been great reluctance to ascribe increased susceptibility to tuberculosis to a simple shortage of calories as such. .Lack of most of the specific nutrients has been blamed at one time or another. The latest study suggests that tuberculous patients do much better if allowed a liberal sugar ration.

In any case, foodstuffs that contain large amounts of carbohydrate must be regarded as indispensable sources of energy and most of them supply other nutrients as well.

\section{Vitamin A}

Before the war, butter and eggs were the chief sources of preformed vitamin $\mathrm{A}$ in our diets. With restrictions of these foodstuffs our daily intake of the preformed vitamin is limited to under 1000 international units. This is not necessarily less than the average before the war, for some of the butter then eaten contained very little vitamin A. Now, all margarine, which has taken the place of a large fraction of our butter, contains 450 units per ounce; as much, that is, as in good butter.

Vitamin A is also obtained from the carotene of green vegetables and yellow roots, particularly carrots. Part of the carotene of our food is absorbed and converted in the liver into vitamin $\mathbf{A}$.
However, it is uncertain how much of this carotene is absorbed; probably there are wide differences between different individuals in their ability to use carotene. As a convention it is assumed, in reckoning the vitamin $A$ value of diets, that onethird of the carotene is converted into vitamin A.

We must now depend on carotene for a large part of our supply of vitamin A. To reach the low level of 3000 units of vitamin A it is necessary to eat larger helpings of vegetables than were usual; it is hardly possible to reach the U.S.A. standard of 5000 units per day. However, gross deficiencies are less likely to occur now than before the war owing to the more uniform distribution of milk and the addition of vitamins to margarine; but minor degrees of deficiency may not be uncommon.

Vitamin A either forms a part of visual purple or co-operates with visual purple in the perception of light. Vitamin A deficiency not only delays dark adaptation in scotopic (rod) vision, but also very definitely affects photopic (cone) vision. There has been much dispute about the validity of the methods of detecting minor degrees of impairment or delay of dark adaptation. At present the various methods are being compared and there is good reason to hope that a satisfactory method is being evolved.

A fair number of experiments have been made in which the effects of deficiency of vitamin A on dark adaptation have been studied. The rate of development and severity of impairment found have varied widely according to the method used. The estimates of minimum requirements of vitamin $A$ have been based mainly on the results of these experiments. As there have been such wide disagreements, it is quite probable that these estimates are too high or too low. Vitamin A deficiency, if severe enough, undoubtedly leads to night blindness, due to this impairment of dark adaptation, and a large proportion of the population must be getting less than the supposed minimum of 3000 units per day; but difficulties in the black-out cannot all be ascribed to impaired dark adaptation. Many other factors are involved in finding the way in semi-darkness.

An entirely distinct effect of vitamin A deficiency is the keratinization of epithelium which may be seen first in the conjunctiva (xerosis). The surface appears dull, dry and wrinkled; later Bitot's spots appear; these are pearly white patches about $2 \mathrm{~mm}$. in diameter. In the more severe degrees the cornea may ulcerate. Kruse (1940) described certain changes in the conjunctiva-loss of translucency of the deeper layers, as seen with the slit-lamp microscope, and injection of capillaries along lines running from the canthus and fornices to the limbus. But according to later investigations, these changes are not the specific effects of deficiency of any vitamin.

In vitamin A deficiency the skin becomes dry and rough. Round or oval papules may be formed, particularly on the fronts and sides of the thighs and backs and sides of the forearms. These papules are caused by hyperkeratosis of the pilo-sebaceous 
follicles. This condition, called phrynodermia, usually clears up on treatment with vitamin A. However, these changes were formerly supposed to be a manifestation of scurvy and in Crandon's experiment (1940), on which he lived on a diet devoid of vitamin $\mathrm{C}$ but supplying abundant vitamin $\mathrm{A}$, these skin lesions appeared after 134 days. It seems that the same change may be caused by deficiency of either vitamin $\mathrm{A}$ or $\mathrm{C}$ and possibly by other deficiencies as well.

\section{Vitamin $B_{1}$ (Aneurin)}

Aneurin is required in the metabolism of pyruvic acid, an intermediate product in the breakdown of glucose. The requirements vary with the amount of glucose, derived either from carbohydrate or protein, that is metabolized. If the diet contains protein, carbohydrate and fat in customary proportion, it is satisfactory to reckon requirements in terms of the ratio of aneurin to total calories. But if the diets contain abnormally high proportions of either fat or carbohydrate the adequacy should be judged by the ratio of aneurin to the non-fat calories derived from carbohydrate and protein (since a large proportion of the protein is metabolized as carbohydrate). Several studies have been made of the effects of restricted intakes of vitamin $B_{1}$. In all these experiments the subjects lost their appetites; they became emotionally unstable, irritable, moody, quarrelsome and depressed; their activities were limited and they failed to co-operate; oedema and cardiac disturbances occurred in some cases. The low intake of $0.1 \mathrm{mgm}$. per 1000 calories caused, in one case, prostration, mental confusion and paralysis of the quadriceps extensor cruris. This subject was eventually cured after treatment with large doses of aneurin for several months. Williams and her colleagues (1942) found that definite symptoms occurred within 24 weeks when not more than $0.22 \mathrm{mgm}$. per 1000 calories was supplied; and that evidence of disturbance of carbohydrate metabolism and depletion of stores of aneurin accompanied by fatigue, irritability, poor appetite, insomnia, soreness of muscles, decreased activity and general feeling of poor health, appeared even when aneurin and calorie ratio rose to $0 \cdot 4 \mathrm{mgm}$. per 1000 . No evidence of deficiency appeared on 0.5 to $0.6 \mathrm{mgm}$. (167 international units) per 1000 calories. However, Ancel Keys (1943) found no symptoms of deficiency nor evidence of disturbance of the carbohydrate metabolism of normal healthy men who were allowed only $0.23 \mathrm{mgm}$. per 1000 calories, for 10 to 12 weeks. The subjects of the experiment of Williams were inmates of Rochester State Hospital who had been under treatment for psychiatric abnormalities; they had recovered and were fully capable of exercising a decision in volunteering for this service. They can hardly be regarded as normal and may have needed particularly large amounts of aneurin. Apart from this, requirements may vary. One factor that increases requirements of vitamin $B_{1}$ is over-activity of the thyroid.
The amount of aneurin per 1000 non-fat calories supplied by various foodstuffs are: national wheatmeal flour, $0.85 \mathrm{mgm}$. (285 inter. units); white flour, 0.159 mgm. (53 inter. units); potatoes, $0.16 \mathrm{mgm}$. (530 inter. units); meat, other than pork, $0.8 \mathrm{mgm}$. (270 inter. units); pork, $8 \mathrm{mgm}$. (2,670 inter. units); skim milk, $0.63 \mathrm{mgm}$. (210 inter. units). The only foodstuff which can now be obtained in appreciable amounts and contains insufficient $B_{1}$ to balance its non-fat calories is sugar. The 8-oz. ration per week provides only 130 calories per day, requiring at most $0.065 \mathrm{mgm}$. (23 inter. units). There is no likelihood of any deficiency of vitamin $B_{1}$ at present. But a return to white flour will bring a risk that the more susceptible will suffer from the minor effects of deficiency.

\section{Vitamin $\mathbf{B}_{\mathbf{2}}$ (Riboflavin)}

In experiments on animals riboflavin has been found to have a remarkable effect on growth. No experiments have been made on the effects of riboflavin alone, on the growth of children. It was probably the decisive factor in experiments with B complex and contributed to the effects of milk found in the classical experiment of Corry Mann (1926). The most characteristic lesion of riboflavin deficiency is cheilosis-reddening and soreness of the lips along the line of closure and fissures at the angles of the mouth; there may also be a scaly, greasy desquamation in the naso-labial folds, on the alae nasae, in the vestibule of the nose and, occasionally, on the ears and eyelids. Cheilosis has been produced experimentally in subjects who have been kept for some 3 or 4 months on a diet deficient in riboflavin alone, or in B complex. All these cases have been cured by riboflavin and not by nicotinic acid. The amounts of riboflavin needed for cure ranged from 0.025 to $\mathbf{0 . 0 7 5} \mathrm{mgm}$. per kilogram of body weight per day (Sebrell and Butler, 1939).

Most of the spontaneous cases of cheilosis have been cured by riboflavin. Some cases, however, have not responded to riboflavin and have been cured by nicotinic acid and a few by pyridoxin. Riboflavin and nicotinic acid are both involved at stages of the same process of glucose metabolism. It might therefore be expected that the effects of deficiencies of the two should overlap, and that these effects should be cured by the vitamin which is most deficient in the diet.

Attention has been focussed, during the last few years, on the changes that can be detected by examination of the eyes with the slit-lamp microscope (Sydenstricker, 1940). It appears now that the only change that is specific evidence of riboflavin deficiency is invasion by capillaries of the cornea within a ring around the inner margin of the limbus. Circum-corneal injection, outside the limbus, is not due to riboflavin deficiency; no changes in vascularization that can be distinguished by the naked eye can be regarded as specific evidence of any deficiency.

Both riboflavin and nicotinic acid (in the form of 
the amide) are constituents of co-enzymes involved in the dehydration of triose phosphate formed in the metabolism of glucose. It might, therefore, be expected, although there is no direct evidence on the point, that requirements of both these vitamins, like those of aneurin, would vary with the amount of glucose metabolized. In the latest experiment on minimum requirements, subjects lived for 288 days on a basal diet which supplied $0.35 \mathrm{mgm}$. of riboflavin per 1000 calories. Although no signs of deficiency appeared, there was evidence of depletion of stores of riboflavin. An intake of $0.5 \mathrm{mgm}$. per 1000 calories was just enough to maintain stores; $0.8 \mathrm{mgm}$. was more than sufficient.

\section{Nicotinic Acid, Nicotinamide (Niacine)}

During the winter of $1937-8$ the main foodstuffs in Madrid were flour and rice; the number of cases of pellagra rose to 115 per month in January 1938 (Jimenez Garcia, 1940). Apart from these relatively few cases of gross disease, many suffered from the less typical manifestations, weakness, insomnia, anxiety and loss of memory; these may be regarded as the 'sub-clinical' evidences of niacine deficiency.

The 'black tongue,' produced when dogs are fed on a pellagra-producing diet, is a necrosis of the floor of the mouth. The resistance of the tissue seems to be reduced and they are attacked by bacteria that normally are saprophytic; the lesions swarm with Vincent's organisms. Similar lesions may occur in dogs deprived of vitamin A. It has been claimed that Vincent's angina and certain forms of stomatitis in men are the result of a lowered resistance due to insufficient nicotinic acid. In some cases treatment with nicotinic acid has been followed by rapid recovery (King, 1943).

It is estimated that a diet that does not supply more than $6.4 \mathrm{mgm}$. per day may cause pellagra; larger amounts should be allowed to prevent minor effects of deficiency. Estimates based on studies of the excretion of nicotinic acid and derivatives are higher. The standard proposed by Bacharach and Drummond (10 mgm. per day) may be regarded as a minimum.

Our daily allowance of both nicotinic acid and riboflavin was reduced by restriction of our meat supply. But this reduction is now nearly balanced by the increase due to the change from white to wheatmeal flour. In the lower income groups that could not afford much meat the intake of nicotinic acid must have increased, although the average daily intake of the whole population (about $12 \mathrm{mgm}$. per day) remains low.

A pint of milk contains about $0.8 \mathrm{mgm}$. of riboflavin. The special allowances of milk for children and for pregnant and nursing women ensure for them a fair daily supply of riboflavin. The milk and solid food of the ordinary adult supplies about $1.2 \mathrm{mgm}$. per day-barely allows $0.5 \mathrm{mgm}$. per 1000 calories which may be insufficient to maintain the body's store of riboflavin. However, it has recently been found that beer contains about as much riboflavin as milk and about $8 \mathrm{mgm}$. of niacine per pint. Half a pint of beer will raise the day's total riboflavin to about $1.6 \mathrm{mgm}$. which should be enough to maintain the body's stocks and will raise the niacine : well above minimum requirements. Tea and meat extracts also add appreciable amounts to the supply of riboflavin.

We have been urged to eat more potatoes. The amounts of nicotinic acid and riboflavin per calorie in potatoes are approximately the same as in wheatmeal flour; so that the daily supply would not be affected by the change from bread to potatoes.

\section{Other Members of the B Group}

A large number of cases of glossitis were treated during the siege of Madrid (Jimenez Garcia, 1940). In the more severe cases the tongue was completely raw and very painful. This glossitis was relatively uncommon when pellagra was at its height and reached its peak of incidence about seven months later. Riboflavin and nicotinic acid produced no improvement, but treatment with brewers' yeast was followed by a rapid cure.

The incidence of optic neuritis ran parallel to those of pellagra and paraesthesia. The symptoms were a serious decline in visual acuity; similar cases have been seen in Africa and ascribed to lack of some member of the vitamin B group.

The occurrence of these deficiency diseases due to lack of some factor other than the better known vitamins, warn us that it is far better to eat natural foodstuffs than to depend on deficient foodstuffs supplemented, as is some white flour, with synthetic vitamins.

\section{Vitamin C (Ascorbic Acid)}

The citrus fruits and tomatoes that were imported before the war contained enough ascorbic acid to provide everyone in Great Britain with $15 \mathrm{mgm}$. per day; also these fruits were obtainable in the spring, when supplies from home sources are at their lowest; they are eaten raw, so that there is no loss of ascorbic acid in cooking. Loss of these imports has cut down our supply of ascorbic acid seriously, and greatly increased the likelihood of some manifestations of vitamin $\mathrm{C}$ deficiency.

The outstanding contribution to the study of vitamin $\mathrm{C}$ deficiency has been Crandon's experiment on himself (1940). He lived for 6 months on a diet supplemented with other vitamins but containing no ascorbic acid. The outstanding symptom was fatigue and weakness which was first noticed after 3 months. He became so weak in the end that he was able to run at seven miles an hour for only sixteen seconds. Papules, similar to those that have been described as manifestation of vitamin $\mathbf{A}$ deficiency, appeared after nineteen weeks. No haemorrhages under the skin were seen until twentythree weeks. The gums were soft and swollen at the end, but never bled. During the thirteenth week of the experiment a piece of muscle was cut out of his back; the wound healed normally. A similar wound was made eleven days before the end 
of the experiment, three weeks after signs of frank scurvy had appeared; after ten days it was found that the wound was not healing under the skin, as intercellular substance was not being formed. The wound healed rapidly when ascorbic acid was given.

In this case wound healing was not impaired until after a long period without ascorbic acid. However, the healing of wounds inflicted on guinea-pigs is impaired when they are allowed as much as $2 \mathrm{mgm}$. of ascorbic acid per day, although $0.5 \mathrm{mgm}$. per day is enough to prevent frank scurvy. On this restricted intake less intercellular material is formed and the arrangement of fibroblasts is disorganized; if bones are broken the calcification of callus is delayed. Also there is considerable evidence that operation wounds may heal badly, if the subjects have not been provided with enough ascorbic acid, although they may show no evidence of frank scurvy. Recently it has been claimed that healing after extraction of teeth is much more rapid, if the subjects are given large doses of ascorbic acid before the extraction.

In Crandon's experiment no evidence of increased capillary fragility was found at any time. In recent investigations on large numbers of people no correlation has been found between the level of ascorbic acid in the plasma or leucocytes and the capillary fragility (Difs, 1940). Increased capillary fragility cannot be regarded as evidence of ascorbic deficiency, although in actual spontaneous scurvy the fragility does not return to normal unless ascorbic acid, as well as vitamin $\mathbf{P}$, is supplied. We have here an instance in which a secondary factor, extrinsic or intrinsic, is involved in the production of a feature of a deficiency disease. A thoroughly healthy person, whose diet is complete in other respects, may show evidences that are considered characteristic of lack of a food constituent only after very long periods of deprivation or not at all:

The League of Nations estimate of ascorbic acid requirements (30 mgm. per day) is largely based on the experiments of Göthlin (1931), who drew his conclusions from measurements of capillary fragility, although he took bleeding from the gums into account. In the light of the later developments with respect to capillary fragility it appears that this standard should be reconsidered.

The part that nutritional deficiencies play in the etiology of gingivo-stomatitis is disputed. The mouth, however, does not differ from other parts of the body; inflammation and ulceration may be due to many causes. A bacillus or virus may be sufficiently virulent to attack a healthy mouth or may only gain a footing when the mucous membrane is damaged by lack of one of several dietary factors. The gums almost always swell and bleed in true scurvy and improve rapidly. when ascorbic acid is given. It is reasonable to suppose that, in some instances, gingivitis is due to vitamin $\mathbf{C}$ deficiency. It has been found that some cases improve rapidly when ascorbic acid is given while others may be better treated with nicotinic acid.

As the war has cut off one of our main sources of ascorbic acid, we have to pay special attention to the remaining sources. Potatoes are our mainstay as large amounts of potatoes are eaten regularly. But potatoes contain on the average about $8 \mathrm{mgm}$. per $100 \mathrm{gm}$., so that the amount that they supply per head per day is about $12 \mathrm{mgm}$., which is not enough. As potatoes are kept, the amount of ascorbic acid that they contain falls. In spring and early summer they may supply only 3 or $4 \mathrm{mgm}$. per day. Other vegetables, which contain ascorbic acid, are scarce at the same time; the best use must be made of the limited supply. Vegetable cells contain an enzyme, ascorbic acid oxidase. When the cells are damaged by bruising or heating, this enzyme is set free and attacks the ascorbic acid. Vegetables should be heated rapidly in order to destroy the enzyme before a large part of the ascorbic acid is lost. When vegetables are heated rapidly to over $80^{\circ} \mathrm{C}$. and cooked for the minimum time the proportion of ascorbic acid destroyed is small, but as much as three-quarters may be dissolved out into the cooking water. Uncooked cabbage for example, may contain $70 \mathrm{mgm}$. per $100 \mathrm{gm}$.; if it is put into the minimum volume of boiling water, heated up rapidly and cooked for 20 minutes the solid may contain $30 \mathrm{mgm}$. per $100 \mathrm{gm}$. and the water some 90 per cent. of the remainder. If vegetables are kept hot for more than half an hour after cooking the further losses of ascorbic acid may be considerable (e.g. one-half in two hours and three-quarters in five). The obvious way of avoiding these losses is to eat green vegetables raw. There are, however, two objections. The amounts of green vegetable that people will eat raw are relatively small although they look big. The normal salad vegetable, lettuce, contains only about $10 \mathrm{mgm}$. of ascorbic acid per $100 \mathrm{gm}$.; a moderate sized lettuce weighs about $50 \mathrm{gm}$. Helpings of salad do not usually exceed $20 \mathrm{gm}$., so that even when the vegetables that contain larger amounts are used, the total is about $14 \mathrm{mgm}$. In the second place, green vegetables are needed to supply carotene. Carotene is not affected by cooking and is less well absorbed from raw food. If cooked vegetables are not eaten the amount of carotene obtained will be insufficient. Although the supply of vitamin $\mathrm{C}$ may well be raised by the use of raw vegetables, abundant cooked vegetables should be eaten as well.

\section{Vitamin. P}

There seems now to be no doubt that capillary resistance is maintained by a vitamin $P$, of which the chemical nature is not known. It is found in fruits and vegetables, but the distribution does not run parallel to that of ascorbic acid; unlike ascorbic acid it is heat stable.

\section{Calcium, Iron and Phytic Acid}

National wheatmeal flour contains about $140 \mathrm{mgm}$. of phytic acid in $100 \mathrm{gm}$. as compared with $15 \mathrm{mgm}$. in white flour. This phytic acid forms insoluble compounds with calcium and iron; McCance and 
Widdowson (1942) and Krebs and Mellanby (1943), have shown that it interferes with the absorption of these two elements. In view of the experience of peoples and groups who have lived all their lives on whole cereals a serious deficiency of calcium and iron seems unlikely. However, it has been reported that the incidence and severity of rickets in Eire has increased since flour of a very high degree of extraction (over 90 per cent.) has been in use. To avoid the risk in Britain, $7 \mathrm{oz}$. of precipitated chalk are now added to the 280-lb. sack of flour.

Iron requirements remain something of a mystery. It was at one time supposed that iron in organic combination, as in haemoglobin, was not available, but this belief has been abandoned. Absorption of iron from the food seems to be regulated by requirements. Very little iron is excreted; iron derived from the breakdown of haemoglobin can be used again. The requirements of men should be negligible; the average loss in menstruation is only $23 \mathrm{mgm}$. per month, so that a few milligrams per day should suffice for women.

There is no evidence that an increase of the iron in the food by a few milligrams, without a change of other constituents of the diet, has any effect on anaemia. Haemoglobin levels may be affected by other nutrients of the diet besides iron; it should not be forgotten that haemoglobin is a protein that contains a large amount of histidine. It is possible that the increase of haemoglobin levels that follows large doses of iron may be comparable with the increased production of plasma protein after doses of iron citrate, found by Pommerenke (1936); low plasma protein cannot be ascribed to iron deficiency.

After nearly two years of wheatmeal bread there is no evidence that Britain is becoming anaemic.

\section{Iodine}

There are areas in Great Britain in which the concentration of iodine in the water supply is low, and the incidence of goitre is high in these areas. With the scarcity of fish, the risk of goitre is considerably increased. The minute amount of iodine required (about 0.014 mgm. per day) can be supplied by the addition of an iodide to table salt.

\section{Canteens and British Restaurants}

The large-scale provision of table d'hôte meals in canteens and British Restaurants gives an opportunity to make good the probable deficiencies in war-time diets. One of these deficiencies, that of animal protein, is met by the extra allowances of meat, cheese and dried milk. Our present food policy is fundamentally the breadstuffs policy of the last war. Bread and flour are cheap and unrationed; they can be bought in unlimited amounts to supply calories. However, people are not guided in their choice of food by requirements, but by custom and appetite. If they can get less of the foodstuffs - butter, jam, meat-which they eat with bread, they are liable to eat less bread, not more, and go short of calories. Canteen and restaurant meals should therefore provide abundant calories. Also, as the main meal of the day, at which vegetables are eaten, they should make good the supply of vitamins $C$ and $A$ with vegetables. In practice it is found that a meal with abundant vegetables that provides over 1000 calories is too bulky for most people to eat before their afternoon's work. Without 1000 calories at the main meal it is difficult to bring the day's total up to requirements. Apart from ultimate loss of weight and health, recent work suggests that the people become irritable when they do not get enough calories-this startling discovery was anticipated in the proverb ' a hungry man is an angry man'.

Another aspect of this fuel problem is the relation of efficiency to the level of blood sugar. Haggard and Greenberg (1935) claim that physical efficiency (that is, the ratio of work done to total energy expanded) and efficiency in the sense of rate and quality of work are impaired when the blood sugar falls. After a breakfast of carbohydrate the blood sugar rises to a peak in about three-quarters of an hour and may then fall to about $70 \mathrm{mgm}$. per 100 c.c. (Conn, 1936). After a breakfast consisting largely of meat the blood sugar remains steady. It is suggested that people now suffer more from low blood sugar and a consequent sinking feeling in the middle of the morning because they eat less meat for breakfast. But I am sceptical about these meat breakfasts. Few workers can afford and few housewives have time to cook a beef-steak breakfast. The change that rationing has brought is that, with less bacon and butter, less fat is eaten; the amount of other more bulky and less appetising foodstuffs eaten is not enough to make up the deficiency of calories.

The remedy both for the fall in blood sugar and for the difficulty of supplying enough calories at the midday meal is to provide a mid-morning snack.

\section{Standards}

The standard proposed by the Food and Nutrition Board of the U.S.A. (Table 1) was adopted by the Conference on Food and Agriculture at Hot Springs as an ultimate goal; it is the standard that is now generally used. When it is attained, there should be no danger of any possibility of impairment of health, growth or efficiency for lack of any nutrient.

Two comments may be made. The allowance of vitamin A may be reconsidered in the light of further studies of impairment of dark adaptation. The allowance of ascorbic acid is sufficient to maintain the ascorbic acid in the plasma above $0.6 \mathrm{mgm}$. per 100 c.c. The evidence that any benefit is derived from an increase above the $30 \mathrm{mgm}$. proposed by the League of Nations is unsatisfactory; but the higher allowance is advisable when the object is to guarantee that it should be adequate under all conditions.

\section{Vitamin Supplements}

The amounts of all the vitamins, other than $\mathbf{B}_{1}$, in the average diet in Great Britain to-day is less 
TABLE 1

DAILY INTAKE OF NUTRIENTS RECOMMENDED BY THE FOOD AND NUTRITION BOARD, NATIONAL RESEARCH COUNCIL, U.S.A.

\begin{tabular}{|c|c|c|c|c|c|c|c|c|c|c|}
\hline & Calories & $\begin{array}{c}\text { Protein, } \\
\text { gm. }\end{array}$ & $\begin{array}{c}\text { Calcium, } \\
\text { gm. }\end{array}$ & $\begin{array}{l}\text { Iron, } \\
\text { mgm. }\end{array}$ & $\begin{array}{l}\text { Vit. A, } \\
\text { Int. } \\
\text { Units }\end{array}$ & $\begin{array}{l}\text { Vit. } B_{1} \text {, } \\
\text { mgm. }\end{array}$ & $\begin{array}{l}\text { Ribo- } \\
\text { flavin, } \\
\text { mgm. }\end{array}$ & $\begin{array}{c}\text { Niacine, } \\
\text { mgm. }\end{array}$ & $\begin{array}{c}\text { Ascorbic } \\
\text { acid, } \\
\text { mgm. }\end{array}$ & $\begin{array}{l}\text { Vit. D, } \\
\text { Int. } \\
\text { Units }\end{array}$ \\
\hline $\begin{array}{cc}\text { MAN }(70 \mathrm{Kgm} .) & \\
\text { Sedentary } & \ldots \\
\text { Moderately active } & . \\
\text { Very active } & . .\end{array}$ & $\begin{array}{l}2500 \\
3000 \\
4500\end{array}$ & 70 & 0.8 & 12 & 5000\{ & $\begin{array}{l}1 \cdot 5 \\
1 \cdot 8 \\
2 \cdot 3\end{array}$ & $\begin{array}{l}2 \cdot 2 \\
2 \cdot 7 \\
3 \cdot 3\end{array}$ & $\begin{array}{l}15 \\
18 \\
23\end{array}$ & 75 & \\
\hline $\begin{array}{l}\text { MAN (56 Kgm.) } \\
\text { Sedentary } \\
\text { Moderately active } \\
\text { Very active } \ldots \\
\text { Pregant (latter half) } \\
\text { Nursing } \quad .\end{array}$ & $\begin{array}{l}2100 \\
2500 \\
3000 \\
2500 \\
3000\end{array}$ & $\begin{array}{r}60 \\
85 \\
100\end{array}$ & $\begin{array}{l}0.8 \\
1.5 \\
2.0\end{array}$ & $\begin{array}{l}12 \\
15 \\
15\end{array}$ & $\begin{array}{l}5000 \\
6000 \\
8000\end{array}$ & $\begin{array}{l}1 \cdot 2 \\
1 \cdot 5 \\
1 \cdot 8 \\
1 \cdot 8 \\
2 \cdot 3\end{array}$ & $\begin{array}{l}1 \cdot 8 \\
2 \cdot 2 \\
2 \cdot 7 \\
2 \cdot 5 \\
3 \cdot 0\end{array}$ & $\begin{array}{r}12 \\
15 \\
18 \\
\cdot 18 \\
23\end{array}$ & $\begin{array}{r}70 \\
100 \\
150\end{array}$ & $\begin{array}{r}400-800 \\
400-800\end{array}$ \\
\hline 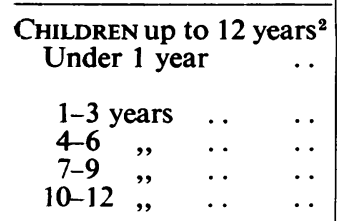 & $\begin{array}{r}100 \\
\text { Kgm. } \\
1200 \\
1600 \\
2000 \\
2500\end{array}$ & $\begin{array}{c}3-4 \\
\text { Kgm. } \\
40 \\
50 \\
60 \\
70\end{array}$ & $\begin{array}{l}1 \cdot 0 \\
1 \cdot 0 \\
1 \cdot 0 \\
1 \cdot 0 \\
1 \cdot 2\end{array}$ & $\begin{array}{r}7 \\
8 \\
10 \\
12\end{array}$ & $\begin{array}{l}2000 \\
2500 \\
3500 \\
4500\end{array}$ & $\begin{array}{l}0 \cdot 6 \\
0 \cdot 8 \\
1 \cdot 0 \\
1 \cdot 2\end{array}$ & $\begin{array}{l}0.6 \\
0.9 \\
1.2 \\
1.5 \\
1.8\end{array}$ & $\begin{array}{r}4 \\
6 \\
8 \\
10 \\
12\end{array}$ & $\begin{array}{l}30 \\
35 \\
50 \\
60 \\
75\end{array}$ & $400-800$ \\
\hline $\begin{array}{rlll}\text { CHILDREN over } 12 \text { years }^{2} \\
\text { Girls: } & 13-15 \text { years } & . \\
& 16-20 & \# & . \\
\text { Boys: } & 13-15 & \# & \ldots \\
& 16-20 & , & \ldots\end{array}$ & $\begin{array}{l}2800 \\
2400 \\
3200 \\
3800\end{array}$ & $\begin{array}{r}80 \\
75 \\
85 \\
100\end{array}$ & $\begin{array}{l}1 \cdot 3 \\
1 \cdot 0 \\
1 \cdot 4 \\
1 \cdot 4\end{array}$ & $\begin{array}{l}15 \\
15 \\
15 \\
15\end{array}$ & $\begin{array}{l}5000 \\
5000 \\
5000 \\
6000\end{array}$ & $\begin{array}{l}1 \cdot 4 \\
1 \cdot 2 \\
1 \cdot 6 \\
2 \cdot 0\end{array}$ & $\begin{array}{l}2 \cdot 0 \\
1 \cdot 8 \\
2 \cdot 4 \\
3 \cdot 0\end{array}$ & $\begin{array}{l}14 \\
12 \\
16 \\
20\end{array}$ & $\begin{array}{r}80 \\
80 \\
90 \\
100\end{array}$ & \\
\hline
\end{tabular}

${ }^{1}$ May be less if provided as preformed vitamin A; more if as carotene.

2 Allowances based on needs for middle year of each period.

Note the large amounts of protein recommended for children and for pregnant and nursing women.

than the amounts recommended in Table 1 . It might be expected that some benefits would follow the administration of vitamins over long periods. On the whole, the results of recent experiments have been disappointing. For example, Jenkins and Yudkin (1943) have reported the results of an experiment in which vitamins $A, B_{1}, C$ and $D$ were given to elementary school children for a year. No difference between these children and a control group in physical capacity, gain in height, weight, haemoglobin, dark adaptation, educational attainment or intelligence, was noticed. There was, however, a slight reduction in the incidence and duration of colds in the supplemented group. The Ministry of Health in collaboration with local health authorities carried out an agreement on a very large scale; this has been reported briefly (Bransby et al., 1944). Vitamins $A, B_{1}, C, D$, riboflavin and nicotinic acid were given. In the studies on children, which were very thorough, no statistically significant effect was produced on rate of growth, nutritional status, muscular strength, condition of teeth and gums or absence from school on account of illness. However, Kohn, Milligan and Wilkinson (1943) selected the boys in one area who showed evidence of deficiency of vitamin $A$ as judged by impairment of dark adaptation (A group), of severe vitamin $C$ deficiency ( $\mathrm{C}$ group) or both (A and $\mathrm{C}$ group), who were receiving no supplements, and compared these with boys in this area receiving supplements. They found that the weight increase in 37 weeks was less in the A group, the endurance less in the $\mathrm{C}$ and AC groups. This suggests that the average supply of the vitamins concerned in our food is enough for the average, but that a fraction of the children get less than they need.

In this same experiment rather less satisfactory studies were made on zinc smelters. No significant effect was found on weight, haemoglobin, blood pressure, absence from illness or output of work.

On the other hand, Harper and others (1943) reported that supplements of vitamin $A, D$ and $C$ to cadets improved vital capacity, breath-holding time, endurance and reduced susceptibility to minor ailments. Frankau (1943) also found that supplements of $\mathbf{4 0} \mathrm{mgm}$. of nicotinamide per day increased efficiency in carrying out fairly severe tests involving physical effort and co-ordination.

It is obvious that supplements of a nutrient will not benefit those who are already receiving enough of it. There may, however, be a few individuals in any group who are not getting as much as they need. These will benefit from supplements, but will be submerged in a statistical analysis of the whole group. The large-scale studies, with sausagemachine methods of statistical analysis, should be supplemented by thorough investigations of small groups. 


\section{Summary}

1. Experience during the siege of Madrid suggests that the more obvious deficiency diseases appear only among the specially susceptible.

2. Certain aspects of the functions of nutrients and effects of deficiency are considered.

3. The protein supply may have an important influence on the rate of recovery from injuries and infections.

4. The vitamins most likely to be deficient in our present diets are A and C. Abundant green vegetables should be eaten to ensure the supply of both of these and care should be taken in cooking in order to prevent destruction of vitamin $\mathrm{C}$.

5. National wheatmeal bread supplies an important fraction of our riboflavin and nicotinic acid; the phytic acid which it contains may interfere with the absorption of calcium and iron.

6. The composition of communal meals and the value of vitamin supplements are discussed.

\section{REFERENCES}

Abelin, I., and Rhyn, E. (1941). Z. Vitam. Forsch., 12,

Bransby, E. R., et al. (1944). Brit. med. J., I, 77.

Brown, W. R., et al. (1938). J. Nutrit., 16, 511.

Burroughs, E. W., et al. (1939). Ibid., 19, 385.

Conn, J. W., and Newburgh, L. H. (1936). J. clin. Invest., 15, 665.

Corry Mann, H. C. (1926). Med. Res. Counc. Rep. No. 105 .

Crandon, J. H., and Lund, C. C. (1940). New England J. Med., 222, 748.

Cuthbertson, D. F. (1935-6). Brit. J. Surg., 23, 505.

Difs (1940). Acta Med. Scand. Suppl., 110.

Drummond, J. C., and Moran, T. (1944). Nature, 153, 99.

Frankau, I. M. (1943). Brit. med. J., 2, 601.

Göthlin, G. F. (1931). Skand. Arch. Physiol., 61, 225.

Haggard, H. W., and Greenberg, L. H. (1935). 'Diet and Physical Efficiency.' New Haven.
Harper, A. A., et al. (1943). Brit. med. J., 1, 243.

Holt, L. E., Albanese, A. A., et al. (1941). Proc. Soc. exp. Biol., N.Y., 48, 726, 728.

- (1942). Federal Proc., 1, 116.

Jenkins, G. N., and Yudkin, J. (1943). Brit. med. J., 2, 265.

Jimenez Garcia, F., and Grande Covian, F. (1940). Rev. Clin. Espan., 1, 318, 323. (1940). Ibid., 1, 231.

Keys, A., et al. (1943). J. Nutrit., 26, 399.

King, J. D. (1943). Brit. dental J., 74, 113.

Knutti, K. E., et al. (1935). J. exp. Med., 61, 127.

Kohn, V., Milligan, E. H. M., and Wilkinson, J. F. (1943). Brit. med. J., 2, 477.

Krebs, H. A., and Mellanby, K. (1943). Biochem. J., 37, 466.

Kruse, H. D. (1940). Publ. Hlth. Rep., Wash., 55, 157. (1940). Ibid., 56, 1301.

McCance, R. A., and Widdowson, E. M. (1942). J. Physiol., 101, 44.

- (1942) Lancet, 1, 588.

Madden, S. C., et al. (1940). J. exp. Med., 71, 283.

McNaught, J. B., et al. (1936). Ibid., 63, 277.

Macrea, T. D., Henry, K. M., and Kon, S. K. (1943). Biochem. J., 37, 225.

Martin, G. J., and Thompson, M. R. (1943). Medicine, 22, 73.

Monro, H. N. and Cüthbertson, D. F. (1943). Biochem. J., 37, XII.

Pommerenke, W. T., et al. (1936). J. exp. Med., 61, 261.

Robinson, W. D., James, J. H., and Grande Covian, F. (1942). J. Nutrit., 24, 557.

Röse, C. (1934). Z. ges. exper. Med., 94, 579.

Rose, W. C. (1943). J. biol. Chem., 148, 437.

Schoenheimer, R., and Rittenberg, D. (1940). Physiol. Rev., $20,218$.

Sebrell, W. H., and Butler, R. E. (1939). Publ. Hlth. Rep., Wash., 54, 2121.

Sydenstricker, V. P., et al. (1940). J. Amer. med. Ass., 114, 243.

Taylor, F. H. L., et al. (1943). Ann. Surg., 118, 215.

Trevorrow, V., et al. (1942). J. Lab. clin. Med., $27,471$.

Whipple, G. H. (1942). Proc. Inst. Med. Chic., 14, 2.

Williams, R. D., et al. (1943). Arch. intern. Med., 71, 38.

_— (1942). Ibid., 69, 721. 